\title{
Complementary and alternative therapy (CAM) in haemophilia pain management: a review of published literature
}

Angela Lambing, Michelle Witkop, Thomas J. Humphries

Pain continues to be a significant issue for people with haemophilia (PWH), whether it is acute pain from a joint bleed, a needle stick when receiving clotting factor treatment, or chronic pain from chronic synovitis and arthritic changes. In the US, there has been controversy and uncertainty regarding the use of oral medications and opioids for the management of chronic pain, including haemophilia pain. Both $\mathrm{PWH}$ and their clinicians have started to explore nonpharmacologic options for managing pain, with many PWH trying to limit their use of oral pain medication and using alternative methods. There is little research around the use of complementary and alternative medicine (CAM) for pain management in the haemophilia community. This paper aims to provide a comprehensive literature review of current English language research on the use of therapies that fall into four distinctive domains of CAM in $\mathrm{PWH}$. English language articles were obtained via searches in Medline, Embase and CINAHL using the target

ANGELA LAMBING

Clinical Support Specialist, Bayer HealthCare, United

States. Email: angela.lambing@ abayer.com

MICHELLE WITKOP, DNP

Head of Research, National Hemophilia Foundation, United States

THOMAS J. HUMPHRIES, MD, FACP

Formerly Senior Medical Director, US Medical Affairs, Bayer HealthCare, United States

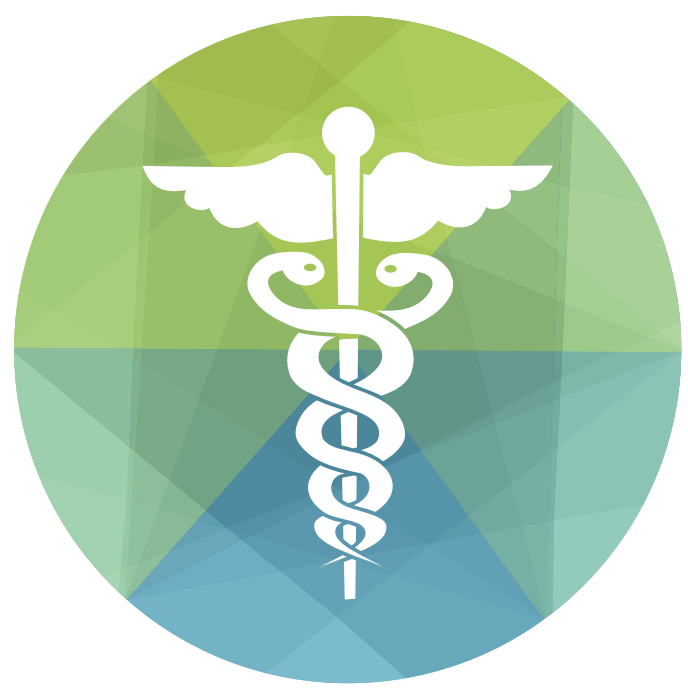

As people with haemophilia are increasingly looking at nonpharmacological ways of managing their pain, healthcare teams should be aware of their potential.

search words "haemophilia" or "bleeding disorders" in combination with other search terms relating to CAM. All references were considered regardless of year. Twenty-three CAM articles that included PWH or other bleeding disorders were identified; ten were evidence based while the remainder provided case reports and descriptions of CAM use in PWH. This indicates that there is limited current research in the area of CAM use for pain management in $\mathrm{PWH}$. Evidence of the benefit of CAM is seen in studies of its use to treat pain in other conditions and healthrelated circumstances. Additional evidenced-based 
CAM research is needed so that alternative pain management therapies can be utilised in a safe and beneficial manner in PWH.

Keywords: Acute pain, bleeding disorders, chronic pain, complementary alternative medicine (CAM), haemophilia, nonpharmacological

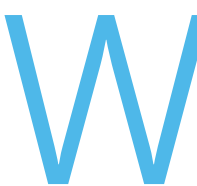

hether from an acute joint bleed or chronic haemarthritic damage from repeated joint bleeding over time, pain is a known complication of haemophilia. The incidence of persistent pain in the haemophilia population ranges from $15 \%$ to $73 \%{ }^{[1-4]}$, with an average self-reported pain level of between 4 and 6 on a 10-point pain scale ${ }^{[4]}$. Timmer et al. reported that symptoms of acute haemarthrosis and haemophilic arthropathy were similar, including pain, swelling, fixed flexed position, reduced range of motion, stiffness and warmth ${ }^{[5]}$. This suggests that people with haemophilia (PWH) have difficulty in determining the difference between pain experiences - a finding initially reported by a national study of pain among $\mathrm{PWH}$ in the United States ${ }^{[4]}$, and further validated in young adults by the IMPACT Quality of Life $(Q \circ L)$ study ${ }^{[6]}$. Further evaluation of the IMPACT QoL data in PWH aged 13-25 years identified the average reported age of pain management initiation was 11.5 years, despite this being a patient population who have benefited from lifelong prophylaxis. Additionally, a discrepancy between the patients' self-reported pain level compared to their caregivers' and providers' perception of their pain was documented.

Both pharmacologic and nonpharmacologic strategies have a role in the management of acute and chronic pain ${ }^{[7]}$, and $\mathrm{PWH}$ are becoming more interested in nonpharmacologic pain management, including complementary and alternative therapy (CAM) options. The use of CAM has been documented in the literature, where $38 \%$ of adults and $12 \%$ of children with non-cancer chronic pain in the United States sought alternative strategies to manage pain effectively ${ }^{[8]}$. Many people reportedly seek CAM as they feel that medical treatments do not always help, they wish to avoid potential side-effects of pain medication, or they seek to manage their pain in a more holistic manner ${ }^{[9]}$.

Jadhav et al. identified $42.3 \%$ of PWH using CAM in a registry of 160 persons with a bleeding disorder, who cited the main reasons for its usage as to reduce bleed frequency, manage pain and control bleeding episodes ${ }^{[10]}$. It has also been reported that patients who experience pain now seek a more comprehensive approach to pain management, as they feel it is patientcentred and promotes self-management of their condition as well as treatment ${ }^{[11]}$.

Various reference guides for practitioners on pain management in PWH are available through national and international organisations such as the United States National Hemophilia Foundation (NHF) ${ }^{[12]}$, the Canadian Hemophilia Society ${ }^{[13]}$ and the World Federation of Hemophilia ${ }^{[14]}$, and through comprehensive articles ${ }^{[15,16]}$. However, few in-depth reviews of CAM pain options specific to $\mathrm{PWH}$ within a randomised study design are available.

This paper aims to provide a comprehensive literature review of current English language research on the use of CAM in PWH, taking into account its four distinct domains.

\section{DEFINING CAM}

CAM is a group of diverse medical and healthcare systems, practices and products that are not presently considered to be part of conventional medicine ${ }^{[17]}$. The United States' National Center for Complementary and Integrative Health $(\mathrm{NCClH})$ defines complementary medicine as a non-mainstream practice used together with conventional medicine, and alternative medicine as a non-mainstream practice used in place of conventional medicine ${ }^{[18]}$. CAM is further clarified by defining complementary, alternative and integrative approaches, as detailed in Table 1. Integrative health combines complementary and alternative therapies, while emphasising a broad-based approach to health and wellbeing that focuses on and treats the whole person rather than just an organ, inclusive of the many domains patients have identified as important to them (eg emotions, function, mental health, social, spiritual, community). This type of care has grown in recent years and is now being researched more frequently ${ }^{[18]}$. Indeed, what is considered to be CAM is in constant flux as therapies that are found to be safe and effective are

\section{Table 1. Definition of CAM ${ }^{[17]}$}

COMPLEMENTARY AND ALTERNATIVE MEDICINE (CAM)

Complementary

- Therapy used with conventional medicine

Alternative

- Therapy used in place of conventional medicine

Integrative

- Combination of conventional medicine and complementary therapy

- Wellness and helping the "whole person" 
Table 2: The four domains of CAM, with examples of therapy

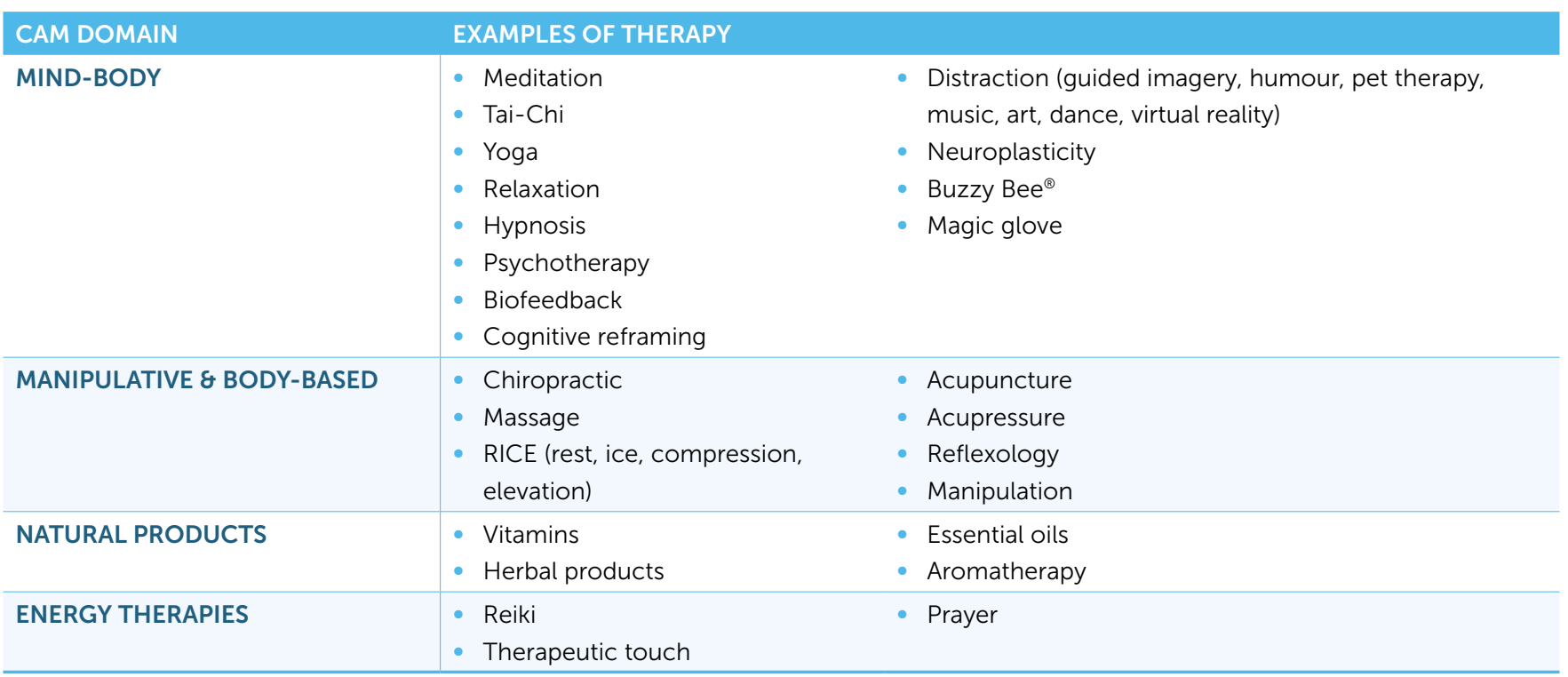

adopted into conventional care ${ }^{[17]}$. A non-exhaustive list of potential CAM therapy is provided in Table 2, categorised by four distinct domains:

- Mind-body therapies

- Manipulative and body-based therapies

- Natural products

- Energy therapies.

\section{LITERATURE REVIEW METHODOLOGY}

English language articles were obtained via searches in Medline, Embase, and CINAHL using the target search words 'haemophilia' and 'bleeding disorders'. These were then connected to additional search words related to CAM and specific therapy types, including meditation, Tai Chi, yoga, relaxation, distraction, cognitive reframing, neuroplasticity, humour, pet therapy, music therapy, art therapy, Buzzy Bee ${ }^{\circledR}$, chiropractic, manipulation, massage, acupuncture, natural products, herbal products, essential oils, aromatherapy, Reiki, therapeutic touch and prayer. The searches were undertaken over a four-month period from June to September 2017. The only selection criteria were the use of CAM with PWH or bleeding disorders. Non-evidence-based articles, case reports and descriptions of therapy were considered alongside evidence-based articles and those involving randomised controlled trials; articles were also included regardless of the date of publication.

\section{RESULTS}

A total of 23 articles that described the use of CAM therapies with $\mathrm{PWH}$ or other bleeding disorders were identified, with publication dates ranging from 1971 to 2017.
Only ten articles were evidenced-based - these are detailed in Table 3, including a description of the articles' aims and results. Only three articles were randomised controlled studies, involving hypnosis ${ }^{[19]}$ and the use of distraction, including virtual reality ${ }^{[20,21]}$ Distraction was also addressed in a cross-sectional study [22]. One longitudinal study was identified using cognitive behavioural therapy ${ }^{[23]}$. A partial cross-over study undertaken in 1985 looked at relaxation exercises in $\mathrm{PWH}^{[24]}$. A pre- and post-test format was used in two studies, on the use of hypnosis and yoga ${ }^{[25,26]}$. A single blinded study and a nonrandomised descriptive study explored acupuncture use in $\mathrm{PWH}^{[27,28]}$

Table 4 outlines all non-evidence-based references that identified CAM usage in PWH. These include case reports, descriptions and a literature review. Case reports were noted in nine references: in mind-

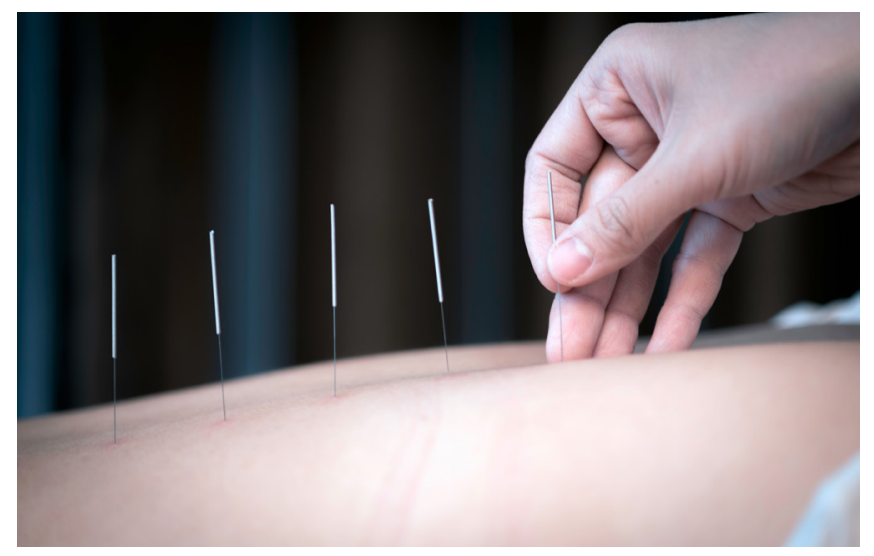

Image: Although limited in number, studies show that people with haemophilia have found therapies including acupuncture, hypnosis, distraction and aromatherapy to be effective in helping to manage pain 
body therapies, including guided imagery ${ }^{[29,30]}$ and hypnosis ${ }^{[31,32]}$, manipulative and body-based modalities, on acupuncture in $\mathrm{PWH}^{[33-35]}$, and in the energy therapy domain, including Reiki (described in blog format) and healing touch [37]. Three references used a descriptive design to evaluate the use of prayer ${ }^{[4]}$, massage ${ }^{[38]}$ and the use of essential oils ${ }^{[39]}$. One literature review looked at the use of biofeedback in $\mathrm{PWH}^{[40]}$.

\section{DISCUSSION}

As $\mathrm{PWH}$ are becoming more interested in using CAM for pain relief, it is important that healthcare providers avail themselves of relevant information so that they are better informed when presented with such requests. There is also an opportunity for healthcare professionals to consider alternative modes of pain management therapy that could be beneficial to PWH. Although CAM therapies can be viewed as having no scientific rationale, the literature review provides evidence indicating that both $\mathrm{PWH}$ and researchers are exploring these methods as alternatives to pain management. This reflects the more general trend in the literature towards exploring CAM with greater interest. Indeed, a more exhaustive review of the literature demonstrating the use of CAM in a variety of health-related pain issues, reveals a number of randomised controlled studies involving all four domains of CAM. These include the use of aromatherapy ${ }^{[41-43]}$ and Reiki ${ }^{[44,45]}$ in women's health, yoga and mindfulness therapies in the treatment of back pain ${ }^{[46,47]}$, Tai Chi and spiritual healing for neck pain ${ }^{[48,49]}$, aromatherapy massage in the treatment of knee pain ${ }^{[50]}$, the use of aromatherapy in burn patients ${ }^{[51,52]}$, aromatherapy massage in female cancer

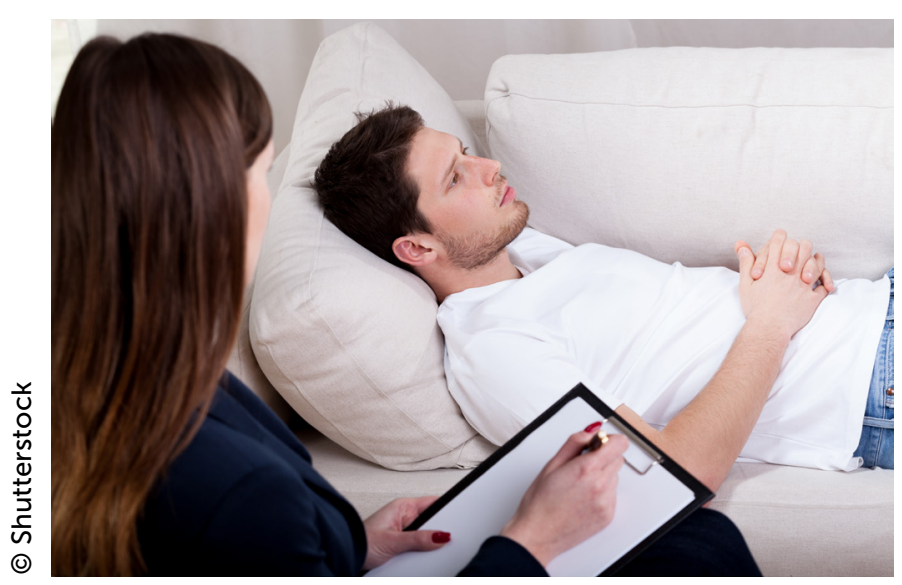

Image: There is scope for further research on the use and effectiveness of CAM for pain management in people with haemophilia. Mind-body therapies, involving techniques such as meditation, mindfulness, biofeedback and distraction, are an area of particular interest patients ${ }^{[53]}$, and aromatherapy and reflexology in rheumatoid arthritis ${ }^{[54]}$.

The provision of pain management should involve a multimodal, personalised approach that best provides optimal benefits to the patient, while evaluating the risk/benefit ratio with each therapy discussed. When determining modes of pain therapy, it is important to consider the financial, cultural, and geographic issues that can affect decisions for treatment modalities, including CAM. To optimise pain management, it is imperative that providers ask the right questions in order to determine what treatment measures may provide a benefit to pain management in $\mathrm{PWH}$. It is equally important to help guide $\mathrm{PWH}$ to qualified and licensed practitioners in specialised therapies, and to maintain ongoing ongoing communication between the PWH and the haemophilia care team during therapy. Determining any factor requirement needed to minimise potential bleeding risk that may arise with the chosen treatment option will always be a key consideration, and may involve additional factor dosing or adjustment of current prophylaxis regimens to coincide with pain treatment plans where the potential for bleeding risk may be higher.

The literature review suggests that there is ample opportunity for future research in all CAM domains, but perhaps particularly in the area of mind-body therapy domain, where neuroplasticity - or the potential for the brain to reorganise and create new neural pathways - plays a key role. Neuroplasticity processes are involved in chronic pain development occurring at the level of the brain cortex, peripheral nerves, and pain receptors. The important consequence of chronic pain neuroplastic changes is the reduced filtering ability of sensory neurons in the brain and spinal cord, resulting in the interpretation of painful stimuli which can potentially be exaggerated or misinterpreted ${ }^{[55]}$. Therapies include, but are not limited to:

- Meditation and mindfulness techniques, where the mind is trained or induced into a level of consciousness involving a present-moment awareness through sensory, emotional, and/or cognitive events ${ }^{[56]}$

- Cognitive behavioural therapy (CBT), where an experienced and trained therapist helps the person in pain reframe their painful experiences to change thoughts and behaviours to improve coping ${ }^{[17]}$

- Biofeedback, where a trained practitioner guides the patient into relaxation using visual or auditory signals, with the intention of disruption the pain-anxietytension cycle, as well as decreasing the stimulation of the sympathetic nervous system ${ }^{[57]}$ 
- Distraction, which involves redirection away from the pain experience using strategies that include, but are not limited to, playing video games, watching television, virtual reality, pet therapy, music and art therapy. Medical devices such as the Buzzy ${ }^{\circledR}$ use a form of distraction based on the gate control theory, where stimulating mechanoreceptors "shuts the gate" to the transmission of sharp pain through presynaptic inhibition. Several studies have shown this to have been particularly effective in children ${ }^{[58-61]}$. Similarly, the Magic glove technique uses visualisation to "numb' the relevant area from pain by guiding the patient to picture it being covered. This technique is frequently used most often in children undergoing venepunctures or IV insertions. ${ }^{[62]}$.

These and other therapies in the mind-body domain have the potential to help PWH manage their pain using nonpharmacological methods, which is arguably of particular importance given the current climate of opioid risk in some parts of the world.

Many of the articles identified during the literature review were completed between 1975 and 1992, and only five evidence-based articles involving the use of CAM in PWH were completed within the last ten years ${ }^{[20-23,27]}$. Additionally, no articles based on a controlled study design were found within the natural products and energy therapy domains of CAM. This suggests that there is ample opportunity for future research in these areas. However, although the number of controlled studies using CAM is relatively low, all the references identified demonstrated some improvement in pain management within the respective technique described.

\section{CONCLUSION}

CAM options for pain management provide a wide variety of strategies that may provide benefits to $\mathrm{PWH}$. Although there may be limited research with respect to CAM as a treatment option by PWH, consideration of its continued use should be explored if there is little or no bleeding risk. If there is limited risk but perceived benefit, it is suggested that continuation of the treatment option may be beneficial.

With the suggested shift away from pharmacologic approaches, it is increasingly important that healthcare professionals caring for PWH become educated in the multiple CAM treatment options available. Patients who defer systemic pain management or choose to augment their treatment plan may seek advice from the haemophilia care team to discuss alternative, nonpharmacological modes of pain management. For PWH, the goal of therapy should be to provide a combination of approaches that will best manage pain.

Well-designed research studies in all areas of CAM pain management options are needed for continued validation of these therapies in $\mathrm{PWH}$. There are many opportunities for future research in this area of pain management.

\section{ACKNOWLEDGEMENTS}

Editorial support was provided by Kathryn Jenner. Haemnet.

The authors have advised no interests that might be perceived as posing a conflict or bias.

This article does not contain any studies involving human participants or animals, performed by any of the authors.

\section{REFERENCES}

1. Buckner T, Witkop M, Wang M, et al. Prevalence, description and management of pain in adult people with hemophilia (PWH): initial lessons from the pain functional impairment and quality of life (P-FIQ study). J Thromb Haemost 2015; 13(Suppl. 2):860.

2. Forsyth $A L$, Witkop $M$, Lambing $A$, et al. Associations of quality of life, pain, and self-reported arthritis with age, employment, bleed rate, and utilization of hemophilia treatment center and health care provider services: results in adults with hemophilia in the HERO study. Patient Prefer Adherence 2015; 9: 1549-60.

3. Humphries TJ, Kessler CM. Managing chronic pain in adults with haemophilia: current status and call to action. Haemophilia 2015; 21: 41-51.

4. Witkop M, Lambing A, Divine G, et al. A national study of pain in the bleeding disorders community: a description of haemophilia pain. Haemophilia 2012; 18(3): e115-9.

5. Timmer MA, Pisters MF, De Kleijn P, et al. Differentiating between signs of intra-articular joint bleeding and chronic arthropathy in haemophilia: a narrative review of the literature. Haemophilia 2015; 21: 289-96.

6. McLaughlin JM, Witkop ML, Lambing A, et al. Better adherence to prescribed treatment regimen is related to less chronic pain among adolescents and young adults with moderate or severe haemophilia. Haemophilia 2014; 20: 506-12.

7. American Pain Society. Principles of Analgesic Use, 7th edn. 2016. Chicago: American Pain Society.

8. Barnes PM, Bloom B. Complementary and alternative medicine use among adults and children: United States, 2007. Natl Health Stat Report 2008: 12; 1-23.

9. Snyder M, Lindquist R. Issues in complementary therapies: how we got to where we are. Online $J$ Issues Nurs. 2001; 6(2). Available from http://ojin.nursingworld.org/ MainMenuCategories/ANAMarketplace/ANAPeriodicals/ OJIN/TableofContents/Volume62001/No2May01/ ComplementaryTherapies/ssues.aspx (accessed 21 January 2019). 
10. Jadhav U, Mukherjee K, Thakur H. Usage of complementary and alternative medicine among severe hemophilia A patients in India. Journal of Evidence-Based Integrative Medicine. 2013; 18(3): 191-7. doi: 10.1177/2156587213484339.

11. Delgado R, York A, Lee C, et al; Active Self-Care Therapies for Pain (PACT) Working Group. Assessing the quality, efficacy, and effectiveness of the current evidence base of active self-care complementary and integrative medicine therapies for the management of chronic pain: a rapid evidence assessment of the literature. Pain Med 2014; 15: S9-20.

12. Witkop M, Lambing A, Fritz R. Pain. In: National Hemophilia Foundation. Nurses' Guide to Bleeding Disorders. Available from https://www.hemophilia.org/sites/default/files/ document/files/Nurses-Guide-Chapter-18-Pain.pdf (accessed 21 January 2019).

13. Canadian Hemophilia Society. Roadmap for managing pain, 2nd edn. 2012. Available from https://www.hemophilia.ca/ wp-content/uploads/2018/05/Roadmap-for-managing-pain. pdf (accessed 21 January 2019).

14. World Federation of Hemophilia. Guidelines for the management of hemophilia, 2nd edn. 2012. Blackwell. Available from http://www1.wfh.org/publications/files/pdf1472.pdf (accessed 21 January 2019).

15. Young G, Tachdjian R, Baumann K, Panopoulos G. Comprehensive management of chronic pain in haemophilia. Haemophilia 2014; 20: e113-20.

16. Riley RR, Witkop M, Hellman E, Akins S. Assessment and management of pain in hemophilia patients. Haemophilia 2011; 17: 839-45.

17. St. Marie B (ed.). Core Curriculum for Pain Management Nursing, 2nd edn. 2010. American Society for Pain Management Nursing

18. National Center for Complementary and Integrative Health. Complementary, alternative, or integrative health: what's in a name? July 2018. Available from https://nccih.nih.gov/health/ integrative-health (accessed 21 January 2018).

19. LaBaw W. Auto-hypnosis in haemophilia. Haematologia (Budap) 1975; 9(1-2): 103-10.

20. Elander J, Robinson G, Morris J. Randomized trial of a DVD intervention to improve readiness to self-manage joint pain. Pain 2011; 152: 2333-41. doi: 10.1016/j.pain.2011.06.026.

21. Dunn A, Patterson J, Biega C. A feasibility and usability study of a nursing orchestrated, customized 3-dimensional virtual reality environment in children with hemophilia undergoing routine intravenous procedures. Blood 2017; 130: 3691.

22. Elander J, Robinson G, Mitchell K, Morris J. An assessment of the relative influence of pain in coping, negative thoughts about pain, and pain acceptance on health-related quality of life among people with hemophilia. Pain 2009; 145; 169-75. doi: 10.1016/j.pain.2009.06.004.

23. Elander B, Morris J, Robinson G. Pain coping and acceptance as longitudinal predictors of health-related quality of life among people with haemophilia-related joint pain. Eur J Pain 2013; 17(6): 929-38. doi: 10.1002/j.15322149.2012.00258.x.

24. Lichstein KL, Eakin TL. Progressive versus self-controlled relaxation to reduce spontaneous bleeding in hemophiliacs. J Behav Med 1975; 8(2): 149-62.
25. Swirsky-Sacchetti T, Margolis CG. The effects of a comprehensive self-hypnosis training program on the use of factor VIII in severe hemophilia. Int J Clin Exp Hypn 1986; 34(2): 71-83.

26. Behestipoor N, Bagheri S, Hashemi F, Zare N, Karimi M. The effect of yoga on quality of life in the children and adolescents with haemophilia. Int J Community Based Nurs Midwifery 2015; 3(2): 150-55.

27. Lambing A, Kohn-Converse B, Hanagavadi S, Varma V. Use of acupuncture in the management of haemophilia pain. Haemophilia 2006; 12: 500-2.

28. Martini A, Schweiger V, Giuffrida A, et al. Acupuncture and auricular cryotherapy for chronic headache in a patient with type III von Willebrand disease. Acupunct Med 2014; 32(5); 432-4. doi: 10.1136/acupmed-2014-010632

29. Varni JW. Self-regulation techniques in the management of chronic arthritic pain in hemophilia. Behav Ther 1981; 12; 18594. doi: doi.org/10.1016/S0005-7894(81)80071-8.

30. Varni JW. Behavioral medicine in hemophilia arthritic pain management: two case studies. Arch Phys Med Rehabit 1981; 62(4): 183-7.

31. Newman M. Hypnotic handling of the chronic bleeder in extraction: a case report. Am J Clin Hypn 1971; 14(2) :126-7.

32. LaBaw W. The use of hypnosis with hemophilia. Psychiatr Med 1992; 10(4): 89-98.

33. Koh TC. Acupuncture therapy in hemophilia: a report of 2 cases. Am J Acupunct 1981; 9(3): 269-70.

34. Rosted $\mathrm{P}$, Jorgensen $\mathrm{V}$. Acupuncture used in the management of pain due to arthropathy in a patient with haemophilia. Acupunct Med 2002; 20(4): 193-5.

35. Wallny TA, Brackmann HH, Gunia G, et al. Successful pain treatment in arthropathic lower extremities by acupuncture in haemophilia patients. Haemophilia 2006; 12: 500-2.

36. Using Reiki for pain relief and stress management. Blog: Haemophilia of Georgia. 4 June 2012. Available from https:// www.hog.org/blog/detail/using-reiki-for-pain-relief-andstress-management (accessed 22 January 2019).

37. Krug P, Kramer D, Bukatman R, Gordon P, Mermelstein $P$. Energy dialogue technique in healing and health: relieving side effects and thyroid dysfunction in a male with haemophilia receiving PEGylated interferon and ribavirin treatment for hepatitis $C$ virus - an anecdotal case study. J Holist Nurs 2013; 31(3): 204-13. doi: 10.1177/0898010113488992.

38. Beyer R, Ingerslev J, Sørensen B. Muscle bleeds in professional athletes: diagnosis, classification, treatment and potential impact in patients with haemophilia. Haemophilia 2010; 16 : 858-65. doi: 10.1111/j.1365-2516.2010.02278.x.

39. Vicol MC. Alternative and traditional healing. In: Loue $S$ (ed.) Mental Health Practitioner's Guide to HIV/AIDS. New York: Springer; 2013. 91-94.

40. Bradley LA, Young LD, Anderson KO, et al. Psychological approaches to the management of arthritis pain. Soc Sci Med 1984; 19(12); 1353-60.

41. Nikjou R, Kazemzadeh R, Rostamnegad M, et al. The effect of lavender aromatherapy on the pain severity of primary dysmenorrhea: a triple-blind randomized clinical trial. Ann Medicine Health Sci Res 2016; 6(4): 211-15.

42. Marzouk TMF, Barakat R, Ragab A, Badria F, Badawy A. Lavender-thymol as a new topical aromatherapy preparation 
for episiotomy: a randomized clinical trial. J Obstet Gynaecol 2015; 35(5): 472-5. doi: 10.3109/01443615.2014.970522.

43. Marzouk TMF, El-Nemer AMR, Baraka HN. The effect of aromatherapy abdominal massage on alleviating menstrual pain in nursing students: a prospective randomized crossover study. Evid Based Complement Alternat Med 2013; 1-2: 742421. doi: 10.1155/2013/742421.

44. Vandervaart $\mathrm{S}$, Berger $\mathrm{H}$, Tam $\mathrm{C}$, et al. The effect of distant reiki on pain in women after elective caesarean section: a double-blinded randomised controlled trial. BMJ Open 2011; 1:e000021. doi: 10.1136/bmjopen-2010-000021.

45. Midilli TS, Esser I. Effects of reiki on post-cesarean delivery pain, anxiety, and hemodynamic parameters: a randomized controlled clinical trial. Pain Manag Nurs 2015; 16(3): 388-99. doi: 10.1016/j.pmn.2014.09.005.

46. Weiland LS, Skoetz N, Pilkington K, et al. Yoga treatment for chronic non-specific low back pain. Cochrane Database Syst Rev 2017; 1:CD010671. doi: 10.1002/14651858.CD010671.pub2.

47. Morone NE, Greco CM, Weiner DK. Mindfulness meditation for the treatment of chronic low back pain in older adults: a randomized controlled pilot study. Pain 2008; 134: 310-19.

48. Lauche R, Stumpe C, Fehr J, et al. The effects of Tai Chi and neck exercises in the treatment of chronic nonspecific neck pain: a randomized controlled trial. J Pain 2016; 17(9): 1013-27. doi: 10.1016/j.jpain.2016.06.004.

49. Gerard S, Smith BH, Simpson JA. A randomized controlled trial of spiritual healing in restricted neck movement. J Altern Complement Med 2004; 9(4): 467-77.

50. Nasiri A, Mahmodi M, Nobakht Z. Effect of aromatherapy massage with lavender essential oil on pain in patients with osteoarthritis of the knee: a randomized controlled clinical trial. Complement Ther Clin Pract 2016; 25; 75-80. doi: 10.1016/j.ctcp.2016.08.002

51. Seyyed-Rasooli A, Salehi F, Mohammadpoorasl A, et al. Comparing the effects of aromatherapy massage and inhalation aromatherapy on anxiety and pain in burn patients: a single-blind randomized clinical trial. Burns 2016; 42(8): 1774-80. doi: 10.1016/j.burns.2016.06.014.

52. Bikmoradi A, Harorani M, Roshanaei G, Moradkhani S, Falahinia $\mathrm{GH}$. The effect of inhalation aromatherapy with damask rose (Rosa damascena) essence on the pain intensity after dressing in patients with burns: a clinical randomized trial. Iran J Nurs Midwifery Res. 2016; 21(3): 247-54. doi: 10.4103/17359066.180380.
53. Ho SSM, Kwong ANL, Wan KWS, Ho RML, Chow KM. Experiences of aromatherapy massage among adult female cancer patients: a qualitative study. J Clin Nurs 2017; 26: 4519-26. doi: 10.1111/jocn.13784.

54. Metin ZG, Ozdemir L. The effects of aromatherapy massage and reflexology on pain and fatigue in patients with rheumatoid arthritis: a randomized controlled trial. Pain Manag Nurs 2016; 17(2): 140-9. doi: 10.1016/j.pmn.2016.01.004.

55. Puretić MB, Demarin V. Neuroplasticity mechanisms in the pathophysiology of chronic pain. Acta Clin Croat 2012; 51(3): 425-9.

56. Lee C, Crawford C, Hickey A. Mind-body therapies for the selfmanagement of chronic pain symptoms. Pain Med 2014; 15 Suppl 1: S21-39. doi: 10.1111/pme.12383.

57. Whitney A. Biofeedback: a way to regain some control over pain. J Fam Pract 2014; 63(6 Suppl): S12-17.

58. Potts DA, Davis KF, Elci OU, Fein JA. A vibrating cold device to reduce pain in the paediatric emergency department: a randomized clinical trial. Pediatr Emerg Care 2017. doi: 10.1097/PEC.0000000000001041. [Epub ahead of print]

59. Moadad N, Kozman K, Shahine R, Ohanian S, Badr LK. Distraction using the BUZZY for children during an IV insertion. J Pediatr Nurs 2016; 64-72. doi: 10.1016/j.pedn.2015.07.010.

60. Kearl YL, Yanger S, Montero S, Morelos-Howard E, Claudius I. Does combined use of the $\mathrm{J}$-tip ${ }^{\circledR}$ and Buzzy ${ }^{\circledR}$ device decrease the pain of venipuncture in a pediatric population? J Pediatr Nurs 2015; 30(6): 829-33. doi: 10.1016/j.pedn.2015.06.007.

61. Canbulat Şahiner N, Inal S, Sevim Akbay A. The effect of combined stimulation of external cold and vibration during immunization on pain and anxiety levels in children. J Perianesth Nurs 2015; 30(3): 228-35. doi: 10.1016/j. jopan.2014.05.011.

62. Kuttner L. The magic glove: a hypnotic pain management technique. Available from http://pediatric-pain.ca/wpcontent/uploads/2013/04/The_Magic_Glove12.pdf (accessed 22 January 2019).

HOW TO CITE THIS ARTICLE:

Lambing A, Witkop M, Humphries TJ. Complementary medicine and alternative therapy (CAM) in haemophilia pain management - a review of published literature. J Haem Pract 2019; 6(1): 7-18. https://doi.org/10.17225/ jhp00122. 
Table 3: Evidenced-based articles from literature review of the use of CAM for pain in people with haemophilia

\begin{tabular}{|c|c|c|c|c|}
\hline $\begin{array}{l}\text { NON- } \\
\text { PHARMACOLOGIC } \\
\text { TREATMENT } \\
\text { OPTIONS }\end{array}$ & $\begin{array}{l}\text { ARTICLE (AUTHOR / } \\
\text { YEAR /REFERENCE) }\end{array}$ & ARTICLE TYPE & INTERVENTIONS/AIMS & RESULTS/OUTCOMES \\
\hline \multicolumn{5}{|c|}{ MIND-BODY THERAPIES } \\
\hline Yoga & $\begin{array}{l}\text { Beheshtipoor et al. } \\
2005 \\
26\end{array}$ & $\begin{array}{l}\text { Semi-experimental } \\
\text { Pre-post-test } \\
\text { design }\end{array}$ & $\begin{array}{l}\text { Evaluate effects of yoga on quality of life in } \\
\text { children and adolescents with haemophilia. } \\
\text { Involved } 27 \text { boys, aged } 8-16 \text { years }\end{array}$ & $\begin{array}{l}\text { Significant differences were noted in quality of life dimensions, number of bleeding } \\
\text { episodes and number of school absences } \\
\text { - Yoga improved the physical, psychological and social domains }\end{array}$ \\
\hline $\begin{array}{l}\text { Relaxation exercises } \\
\text { Guided imagery }\end{array}$ & $\begin{array}{l}\text { Lichstein et al. } \\
1985 \\
24\end{array}$ & $\begin{array}{l}\text { Combined multiple } \\
\text { baseline partial } \\
\text { cross-over design }\end{array}$ & $\begin{array}{l}\text { Effects of progressive and self-controlled } \\
\text { relaxation on spontaneous bleeding and } \\
\text { collateral symptoms. } \\
\text { Seven PWH }\end{array}$ & $\begin{array}{l}\text { - No strong evidence that the treatment affected bleeding frequency or perceived pain } \\
\text { - Results failed to replicate previous findings and cast doubt on the stress theory of } \\
\text { spontaneous bleeding } \\
\text { - Further research is needed to clarify the role of psychological interventions for PWH }\end{array}$ \\
\hline \multirow[t]{3}{*}{ Distraction } & $\begin{array}{l}\text { Elander et al. } \\
2009 \\
22\end{array}$ & $\begin{array}{l}\text { Cross-sectional } \\
\text { study }\end{array}$ & $\begin{array}{l}\text { Evaluation of influence of active pain coping, } \\
\text { passive adherence coping and negative } \\
\text { thoughts about pain, activity engagement } \\
\text { and pain willingness on physical and mental } \\
\text { aspects of quality of life. } \\
209 \text { men with haemophilia A or B. }\end{array}$ & $\begin{array}{l}\text { - Pain intensity had the main influence on physical quality of life; negative thoughts had } \\
\text { the main influence on mental quality of life } \\
\text { - Activity engagement and pain willingness had small but significant influences on } \\
\text { physical and mental quality of life } \\
\text { - Pain willingness mediated the influence of pain intensity on physical quality of life and } \\
\text { activity engagement } \\
\text { - Pain willingness mediated the influence of negative thoughts on mental quality of life } \\
\text { - Negative thoughts moderated the influence of pain intensity on mental quality of life } \\
\text { - There was no evidence that active pain coping influenced quality of life } \\
\text { interventions to increase pain acceptance and reduce negative thoughts about pain }\end{array}$ \\
\hline & $\begin{array}{l}\text { Elander et al. } \\
2011 \\
20\end{array}$ & $\begin{array}{l}\text { Randomised } \\
\text { controlled trial }\end{array}$ & $\begin{array}{l}\text { Two-phase motivational-volitional model } \\
\text { of readiness to self-manage pain, including } \\
\text { the personal experiences of PWH. } \\
164 \text { PWH with arthritic pain }\end{array}$ & $\begin{array}{l}\text { Findings are consistent with a two-phase, motivational-volitional model of pain self- } \\
\text { management, and provide the first insights in our knowledge of readiness to self- } \\
\text { manage pain in PWH } \\
\text { - Low-intensity interventions in DVD format can improve the motivational impact of } \\
\text { written information and could be used to help prepare people with chronic pain for } \\
\text { more intensive self-management interventions }\end{array}$ \\
\hline & $\begin{array}{l}\text { Dunn et al. } \\
2017 \\
21\end{array}$ & $\begin{array}{l}\text { Single centre } \\
\text { randomised 2:1 } \\
\text { pilot study }\end{array}$ & $\begin{array}{l}\text { Evaluating the difference in procedure time } \\
\text { of IV insertion with use of virtual reality in } \\
\text { children with haemophilia. } \\
25 \text { children with haemophillia, median age } \\
12.2 \text { years }\end{array}$ & $\begin{array}{l}\text { - Children and their parents viewed the virtual reality (VR) method as a positive distraction } \\
\text { - No adverse disruption in clinic flow } \\
\text { - No significant difference in group allocation between sex, age, type of haemophilia, } \\
\text { - Median VR procedure time was ten minutes } \\
\text { - No difference in scores between groups in terms of nervousness prior to IV, or impact } \\
\text { of distraction technique on level of engagement, impact on pain, anxiety or likability. } \\
\text { In the VR cohort, the median scores for ease of use and desire to use VR for future } \\
\text { procedures was highly positive for patients, nurses and parents }\end{array}$ \\
\hline
\end{tabular}


ARTICLE (AUTHOR YEAR /REFERENCE)

\section{OPTIONS}

Cognitive reframing

er et al.

\begin{tabular}{|c|c|}
\hline & 23 \\
\hline \multirow[t]{2}{*}{ Hypnosis } & $\begin{array}{l}\text { Swirsky-Sacchetti, } \\
\text { Margolis } \\
1986 \\
25\end{array}$ \\
\hline & $\begin{array}{l}\text { LaBaw } \\
1975 \\
19\end{array}$ \\
\hline \multicolumn{2}{|c|}{ MANIPULATIVE AND BODY-BASED THER } \\
\hline \multirow[t]{2}{*}{ Acupuncture } & $\begin{array}{l}\text { Wallny et al. } \\
2006 \\
35\end{array}$ \\
\hline & $\begin{array}{l}\text { Lambing et al } \\
2012 \\
27\end{array}$ \\
\hline
\end{tabular}
descriptive
ARTICLE TYPE

Longitudinal study

\section{INTERVENTIONS/AIMS}

RESULTSIOUTCOMES to promote readiness to self-manage chronic joint pain.

101 male PWH

\section{Random design \\ Study of comprehensive self-hypnosis}

Pre-post-test

design

Randomised

controlled study

\section{RESULTS/OUTCOMES} mental quality of life training to decrease stress and assess

amount of clotting factor usage for bleeding

in persons trained in hypnosis vs controls.

30 severe $\mathrm{PWH}$ randomly assigned.

Randomised to hypnosis therapy

or control group.

$20 \mathrm{PWH}$ participated
Reduced pain intensity predicted better physical quality of life regardless of age

haemophilia severity, baseline pain intensity and baseline physical quality of life

- Lower baseline passive coping and changed (increased) pain acceptance predicted

better mental quality of life, regardless of age, haemophilia severity and baseline

- Increased activity engagement predicted better mental quality of life

- Reduced negative thoughts predicted better mental quality of life

- Active pain coping did not predict physical or mental QoL

- The general level of distress was significantly reduced in the treatment group

- Treatment significantly reduced the amount of factor concentrate used to control bleeding in comparison to controls

- Statistical analysis of the data confirmed the clinical observation of a greater improvement among patients in the experimental group in reduction of transfused products

Single blinded study PWH with joint pain; non-pain side used as control. $12 \mathrm{PWH}$ participated

- Reduction in pain in 10 of $12 \mathrm{PWH}$ after acupuncture treatments

- No procedural bleeding noted

- Pain reduced from 6.8 to 5/10 per visual analogue scale

Non-randomised, (i) Identify effects of acupuncture use in PWH who experience persistent joint pain due to haemarthrosis; (ii) document no

- Seven out of nine PWH reported an improvement in pain scores and quality of life reported increased bleeding risk as a result of acupuncture use.

Six US subjects received prophylaxis factor prior to acupuncture; three subjects from India received no factor prior to treatments. 
Table 4: Non-evidenced-based articles from literature review of the use of CAM for pain in people with haemophilia

\begin{tabular}{|c|c|c|c|c|}
\hline $\begin{array}{l}\text { NON- } \\
\text { PHARMACOLOGIC } \\
\text { TREATMENT } \\
\text { OPTIONS }\end{array}$ & $\begin{array}{l}\text { ARTICLE (AUTHOR / } \\
\text { YEAR /REFERENCE) }\end{array}$ & ARTICLE TYPE & INTERVENTIONS/AIMS & RESULTS/OUTCOMES \\
\hline \multicolumn{5}{|c|}{ MIND-BODY THERAPIES } \\
\hline \multirow[t]{2}{*}{$\begin{array}{l}\text { Relaxation exercises } \\
\text { Guided imagery }\end{array}$} & $\begin{array}{l}\text { Varni } \\
1981 \\
29\end{array}$ & Case report & $\begin{array}{l}\text { Training in use of progressive muscle } \\
\text { relaxation, meditative breathing and guided } \\
\text { imagery. } \\
\text { Two PWH with chronic arthritic pain }\end{array}$ & $\begin{array}{l}\text { - Imagery training resulted in clinical reduction in arthritic pain } \\
\text { - Subjects were able to demonstrate thermal control of their joints } \\
\text { - An increase in thermal heat at the joint resulted in decreased pain perception }\end{array}$ \\
\hline & $\begin{array}{l}\text { Varni } \\
1981 \\
30\end{array}$ & Case report & $\begin{array}{l}\text { Training in self-regulation techniques } \\
\text { including progressive muscle relaxation } \\
\text { exercises, meditative breathing and guided } \\
\text { imagery. } \\
\text { Three PWH with chronic arthritic pain }\end{array}$ & $\begin{array}{l}\text { - Clinically significant reductions in arthritic pain perception for all three PWH were } \\
\text { noted, with maintenance demonstrated at } 12,14 \text { and } 7 \text { months, respectively } \\
\text { - Overall improvements in pain, sleep and mobility, and decrease in analgesic use } \\
\text { - Physiological assessment of surface skin temperature at the arthritic joints }\end{array}$ \\
\hline Biofeedback & $\begin{array}{l}\text { Bradley et al. } \\
1984 \\
40\end{array}$ & Literature review & $\begin{array}{l}\text { Mind body therapies used in PWH with } \\
\text { rheumatoid arthritis }\end{array}$ & $\begin{array}{l}\text { - Review of studies by Varni (references } 29 \text { and 30), LaBaw (reference 19), and Swirsky- } \\
\text { Sacchetti and Margolis (reference 25) }\end{array}$ \\
\hline \multirow[t]{2}{*}{ Hypnosis } & $\begin{array}{l}\text { Newman } \\
1971 \\
31\end{array}$ & Case report & $\begin{array}{l}\text { Hypnosis training in a } 43 \text { year-old female } \\
\text { bleeding patient for tooth extraction }\end{array}$ & - No bleeding reported during surgical extraction \\
\hline & $\begin{array}{l}\text { LaBaw } \\
1992 \\
32\end{array}$ & Case report & $\begin{array}{l}\text { Education of PWH on self-hypnosis. } \\
\text { Two case reports }\end{array}$ & $\begin{array}{l}\text { - Subject was able to control bleeding and continue family vacation } \\
\text { - Five-year-old boy using hypnosis }>10 \text { years; self-reported reduction of factor infusions } \\
\text { needed by } 50 \% \\
\text { - } 19 \text {-year-old able to reduce hospitalisations from bleeding episodes; prior to } \\
\text { succumbing to AIDS; able to use hypnosis to avoid terminal hospitalisation }\end{array}$ \\
\hline \multicolumn{5}{|c|}{ MANIPULATIVE AND BODY-BASED THERAPIES } \\
\hline Massage therapy & $\begin{array}{l}\text { Beyer et al. } \\
2010 \\
38\end{array}$ & Descriptive & Massage therapy in PWH & $\begin{array}{l}\text { - Treatment and preventive strategies include RICE (rest, ice, compression and } \\
\text { elevation), protected mobilisation, stretching and strengthening exercises, manual } \\
\text { therapy (articular, neural and soft tissue mobilisation and massage), and correction of } \\
\text { movement dysfunction, functional rehabilitation and electrotherapeutic interventions } \\
\text { - Improved circulation and range of motion noted }\end{array}$ \\
\hline Acupuncture & $\begin{array}{l}\text { Koh } \\
1981 \\
33\end{array}$ & Case report & $\begin{array}{l}\text { Patient \#1: } 40 \text {-year-old PWH with left } \\
\text { shoulder osteoarthritis } \\
\text { Patient \#2: } 36 \text {-year-old PWH with right } \\
\text { knee and ankle pain }\end{array}$ & $\begin{array}{l}\text { - Patient \#1 free of pain for more than five months post-treatments } \\
\text { - Patient \#2: reduction of oral pain medication } \\
\text { - Both patients tolerated treatments well with no complications } \\
\text { - PWH should receive factor treatment prior to acupuncture therapy }\end{array}$ \\
\hline
\end{tabular}




\begin{tabular}{|c|c|c|c|c|}
\hline $\begin{array}{l}\text { NON- } \\
\text { PHARMACOLOGIC } \\
\text { TREATMENT } \\
\text { OPTIONS }\end{array}$ & $\begin{array}{l}\text { ARTICLE (AUTHOR / } \\
\text { YEAR /REFERENCE) }\end{array}$ & ARTICLE TYPE & INTERVENTIONS/AIMS & RESULTS/OUTCOMES \\
\hline & $\begin{array}{l}\text { Rosted, Jorgenson } \\
2002 \\
34\end{array}$ & Case report & $\begin{array}{l}\text { 38-year-old PWH who received three } \\
\text { elbow treatments and five knee treatments }\end{array}$ & $\begin{array}{l}\text { - Patient reported a reduction in pain and opioid usage } \\
\text { - Repeat acupuncture every three months as needed provided continued improvement }\end{array}$ \\
\hline & $\begin{array}{l}\text { Martini et al. } \\
2014 \\
28\end{array}$ & Case report & $\begin{array}{l}\text { 43-year-old female with type III von } \\
\text { Willebrand's disease and chronic migraines }\end{array}$ & $\begin{array}{l}\text { - Improvement in migraine pain without bleeding or bruising } \\
\text { - No adverse effects of somatic needling noted } \\
\text { - No auricular cryostimulation reported } \\
\text { - No bleeding reported }\end{array}$ \\
\hline \multicolumn{5}{|c|}{ NATURAL PRODUCTS } \\
\hline $\begin{array}{l}\text { Aromatherapy and } \\
\text { essential oils }\end{array}$ & $\begin{array}{l}\text { Vicol } \\
2013 \\
39\end{array}$ & Descriptive & $\begin{array}{l}\text { Aromatherapy to manage side-effects of } \\
\text { HIV }\end{array}$ & - Under study for potential benefit in treating hepatitis $C$ and haemophilia \\
\hline \multicolumn{5}{|l|}{ ENERGY THERAPY } \\
\hline Reiki & $\begin{array}{l}\text { HoG blog } \\
2012 \\
36\end{array}$ & $\begin{array}{l}\text { Case report } \\
\text { (personal) }\end{array}$ & $\begin{array}{l}\text { Use of Reiki to help with back pain } \\
\text { following car accident }\end{array}$ & $\begin{array}{l}\text { - First session yielded noticeable pain relief and muscle relaxation. } \\
\text { - Subsequent sessions continued to relieve pain and increased time between muscle } \\
\text { - spasms }\end{array}$ \\
\hline Therapeutic touch & $\begin{array}{l}\text { Krug et al. } \\
2013 \\
37\end{array}$ & $\begin{array}{l}\text { Case report } \\
\text { (abstract) }\end{array}$ & $\begin{array}{l}\mathrm{PWH} \text { with hepatitis } \mathrm{C} \text { receiving therapeutic } \\
\text { touch }\end{array}$ & $\begin{array}{l}\text { - } 30-40 \% \text { relief in fatigue and pain. } \\
\text { - Normalisation of thyroid function }\end{array}$ \\
\hline Prayer & $\begin{array}{l}\text { Witkop et al. } \\
2012 \\
4\end{array}$ & Description & $\begin{array}{l}\text { - Identify language used by PWH to } \\
\text { describe pain } \\
\text { - Describe pharmacological and } \\
\text { nonpharmacological methods of pain } \\
\text { management used } \\
\text { - Determine perceived effectiveness of } \\
\text { pain management } \\
\text { - Determine which healthcare practitioner } \\
\text { manages pain in PWH } \\
\text { - } 764 \text { PWH self-reported results }\end{array}$ & $\begin{array}{l}\text { - The use of prayer to manage acute pain }(28 \% \mathrm{~N}=189 ;) \text { and chronic pain }(29 \% \mathrm{~N}=170) \text {, } \\
\text { and faith for acute pain }(21 \%) \mathrm{N}=137 \text {, and chronic pain ( } 22 \%) \mathrm{N}=130\end{array}$ \\
\hline
\end{tabular}




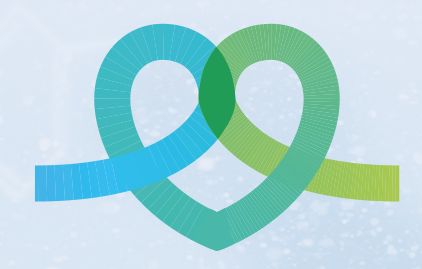

\section{The Journal of Haemophilia Practice}

An open-access journal for sharing experience in the care of people with bleeding disorders 